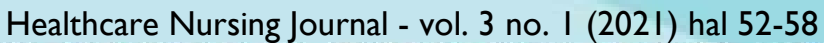

\section{ANALISIS FAKTOR PEMBERIAN IMUNISASI DASAR LENGKAP PADA BAYI DI PUSKESMAS TAMALATE MAKASSAR}

\author{
Muhammad Thabran Talib', Satriani Albar ${ }^{2}$ \\ 'STIKES Panakkukang Makassar \\ ${ }^{2}$ RSUD Haji Makassar
}

Article Information

Received: Desember 3th, 2020

Revised: January 1th, 2021

Available online: January, 2021

\section{Keywords}

Imunisasi, Pengetahuan, Sikap

\section{Correspondence}

Phone: (+62)81342702726

E-mail:

thabrantalib7@gmail.com

\begin{abstract}
Pemberian imunisasi dapat dilihat dari banyaknya balita yang meninggal akibat penyakit dapat dicegah dengan imunisasi. Data World Health Organization menunjukkan bahwa satiap tahun, setidaknya 1,7 juta anak meninggal karena penyakit yang dapat dicegah dengan vaksin yang sudah tersedia. Penelitian ini bertujuan untuk menganalisis faktor pemberian imunisasi dasar lengkap antara pengetahuan dan sikap ibu tentang imunisasi. Penelitian Puskesmas Tamalate Makassar. Populasi adalah ibu yang memiliki anak usia imunisasi di Puskesmas Tamalate Makassar dengan jumlah sampel 122 orang. Data sekunder dari laporan tahunan imunisasi yang ada di Puskesmas Tamalate Makassar, data primer dengan pembagian kuisioner yang diisi responden. Analisa data dilakukan yaitu analisa Univariat dan analisa bivariat. Penelitian ini dilaksanakan pada NopemberDesember 2019. Dengan jenis penelitian Desain dengan Cross Sectional Study. Hasil penelitian analisa univariat, pengetahuan baik $107(87,7 \%)$ responden dan pengetahuan responden yang kurang $15(12,2 \%)$ responden. Sedangkan sikap baik $115(94,2 \%)$ responden, sedangkan sikap yang kurang $7(5,7 \%)$ responden. Analisis bivariat menunjukkan Ada hubungan yang bermakna antara tingkat pengetahuan dengan pemberian imunisasi dasar lengkap pada bayi yaitu p: 0,002 dan ada hubungan yang bermakna antara sikap dengan pemberian imunisasi dasar lengkap pada bayi yaitu p: 0,038. Saran yaitu upaya peningkatan pembinaan dan pendidikan tentang pentingnya pemberian imunisasi secara lengkap pada bayi.
\end{abstract}

\section{PENDAHULUAN}

Program imunisasi sudah berkembang cukup pesat, terbukti dengan menurunnya angka kesakitan dan angka kematian bayi. Angka kesakitan bayi menurun $10 \%$ dari angka sebelumnya, sedangkan angka kematian bayi menurun $5 \%$ dari angka sebelumnya menjadi 1,7 juta kematian setiap tahunnya di Indonesia. (Dirjen YanMed RI, 2015). Pentingnya pemberian imunisasi dapat dilihat dari banyaknya balita yang meninggal akibat Penyakit Dapat Dicegah Dengan Imunisasi (PD3I). Data World Health Organization (WHO) menunjukkan bahwa satiap tahun, setidaknya 1,7 juta anak maninggal karena 
penyakit yang dapat dicegah dengan vaksin yang sudah tersedia. Hal ini sebenarnya tidak perlu terjadi karena penyakit-penyakit tersebut dapat dicegah dengan imunisasi. Karena itulah, imunisasi harus dilakukan secara tepat. Orang tua harus mengetahui mengapa, kapan, dimana dan beberapa kali anaknya harus mendapatkan imunisasi (Vina et al, 2017). Upaya untuk mencapai tujuan berbagai program dengan berbasis Primary Health Care telah dilaksanakan untuk meningkatkan derajat kesehatan. Beberapa indikator yang digunakan WHO untuk mengukur tingkat keberhasilan program program tersebut, antara lain Angka Kematian Bayi, Angka Kematian Balita (AKB), Angka Kematian Ibu (AKI) dan Angka Harapan Hidup (life ecpectancy). Indikator kesehatan dalam Sustainable Development Goals (SDGs) 2030 yang merupakan goals ketiga yaitu jaminan kesehatan dan promosi kesehatan bagi semua umur (Kemenkes RI, 2015). Data Riset Kesehatan Dasar 2018 menunjukkan bahwa 32,9\% bayi di Indonesia tidak mendapatkan imunisasi dasar lengkap dan 9,2\% bayi tidak melakukan imunisasi meningkat dari tahun 2013 yaitu 32,1\% (Balitbangkes, 2018). Tujuan penelitian adalah diketahuinya faktor pengetahuan ibu dengan pemberian imunisasi dasar lengkap pada bayi dan diketahuinya sikap ibu dengan pemberian imunisasi dasar lengkap pada bayi.

\section{METODE}

Desain penelitian dengan Deskriptif untuk mengetahui dan menganalisis hubungan antara variabel yang terdiri atas dua variable yaitu variable bebas dan terikat. Dengan pendekatan Cross Sectional Study yang merupakan rancangan penelitian dengan melakukan pengukuran atau pengamatan pada saat bersamaan (sekali waktu) antara faktor risiko pengetahuan dan sikap dengan pemberian imunisasi lengakp dan tidak lengkap. Pengolahan data dengan uji statistik dengan Chi-Square antara variabel hingga diperoleh hasil Fisher Exact Test. Alat dan bahan yang digunakan yaitu instrumen kuisioner, alat tulis menulis dan komputer untuk mengolah data penelitian.

\section{HASIL DAN PEMBAHASAN}

\section{Hasil Penelitian}

Tabel 1: Karakteristik responden berdasarkan Umur Ibu di Puskesmas Tamalate Makassar, Desember 2019

\begin{tabular}{ccc}
\hline Umur Ibu & Jumlah & Persentese \\
\hline $18-25$ & 36 & 29,5 \\
$26-35$ & 45 & 36,9 \\
$36-45$ & 35 & 28,7 \\
$>45$ & 6 & 4,9 \\
\hline Jumlah & 122 & 100 \\
\hline
\end{tabular}

Sumber: Data Primer

Tabel 1 didapatkan hasil bahwa responden yang paling sedikit jumlahnya yaitu pada umur $>45$ tahun sebanyak $6(4,9 \%)$ reponden dan yang paling banyak jumlahnya yaitu pada umur 26-35 tahun sebanyak $45(36,9 \%)$ responden.

Tabel 2: Karakteristik Responden berdasarkan pekerjaan ibu di Puskesmas Tamalate Makassar, Desember 2019

\begin{tabular}{ccc}
\hline Pekerjaan & Jumlah & Persentese \\
\hline IRT & 105 & 86,1 \\
PNS & 5 & 4,1 \\
Wiraswasta & 12 & 9,8 \\
\hline Jumlah & 122 & 100 \\
\hline
\end{tabular}

Sumber: Data Primer

Tabel 2 didapatkan hasil bahwa yang paling mendominasi jumlahnya yaitu pekerjaan sebagai Ibu Rumah Tangga (IRT) sebanyak 105(86,1\%) responden dan yang paling rendah jumlahnya yaitu PNS sebanyak $5(4,1 \%)$ responden.

Tabel 3: Karakteristik Responden berdasarkan pekerjaan ibu di Puskesmas Tamalate Makassar, Desember 2019

\begin{tabular}{ccc}
\hline Pekerjaan & Jumlah & Persentese \\
\hline IRT & 105 & 86,1 \\
PNS & 5 & 4,1 \\
Wiraswasta & 12 & 9,8 \\
\hline Jumlah & 122 & 100 \\
\hline
\end{tabular}

Sumber: Data Primer

Tabel 3 didapatkan hasil bahwa yang paling mendominasi jumlahnya yaitu pekerjaan sebagai Ibu Rumah Tangga (IRT) sebanyak 105(86,1\%) 
responden dan yang paling rendah jumlahnya yaitu PNS sebanyak 5(4,1\%) responden.

Tabel 4: Distribusi Responden berdasarkan Pengetahuan tentang imunisasi di Puskesmas Tamalate Makassar, Desember 2019

\begin{tabular}{ccc}
\hline Pengetahuan & Jumlah & Persentese \\
\hline Kurang & 15 & 12,3 \\
Baik & 107 & 87,7 \\
\hline Jumlah & 122 & 100,0 \\
\hline
\end{tabular}

Sumber: Data Primer

Tabel 4 diatas, dapat diketahui bahwa pengetahuan responden yang baik yaitu $107(87,7 \%)$ responden sedangkan pengetahuan responden yang kurang yaitu 15(12,3\%) responden

Tabel 5: Distribusi Responden berdasarkan sikap tentang imunisasi di Puskesmas Tamalate Makassar, Desember 2019

\begin{tabular}{ccc}
\hline Sikap & Jumlah & Persentese \\
\hline Kurang & 7 & 5,7 \\
Baik & 115 & 94,3 \\
\hline Jumlah & 122 & 100,0 \\
\hline
\end{tabular}

Sumber: Data Primer

Tabel 5 dapat diketahui bahwa sikap responden yang baik yaitu $115(94,3 \%)$ responden sedangkan sikap responden yang kurang ada $7(5,7 \%)$ responden.

Tabel 6: Distribusi Responden berdasarkan pemberian imunisasi di Puskesmas Tamalate Makassar, Desember 2019

\begin{tabular}{ccc}
\hline $\begin{array}{c}\text { Pemberian } \\
\text { imunisasi }\end{array}$ & Jumlah & Persentese \\
\hline Tidak lengkap & 6 & 4,9 \\
Lengkap & 116 & 95,1 \\
\hline Jumlah & 122 & 100,0 \\
\hline
\end{tabular}

Sumber: Data Primer

Tabel 6, dapat diketahui bahwa responden dengan pemberian imunisasi lengkap sebanyak 116 (95,1\%) responden sedangkan responden dengan pemberian imunisasi tidak lengkap sebanyak $6(4,9 \%)$ responden.

Pengetahuan dengan pemberian imunisasi

Tabel 7: Hubungan tingkat pengetahuan responden dengan pemberian imunisasi dasar lengkap pada bayi di Puskesmas Tamalate Makassar, Desember 2019

Pengetahuan $\quad$ Pemberian $\quad$ Total

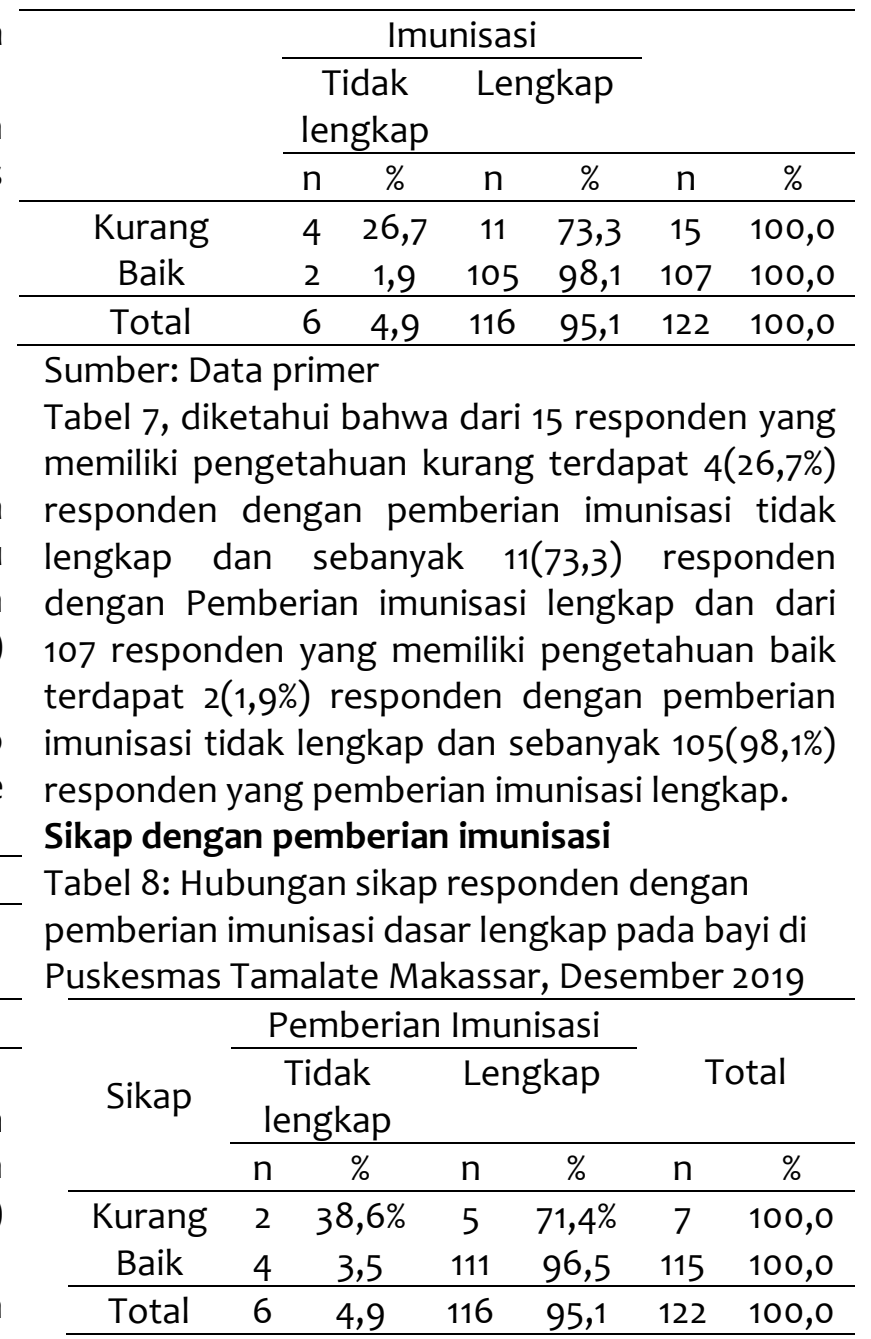

Sumber: Data primer

Tabel 8 diketahui bahwa dari 7 responden yang memiliki sikap kurang dalam pemberian imunisasi terdapat $2(38,6 \%)$ responden dengan pemberian imunisasi tidak lengkap dan $5(71,4 \%)$ responden dengan pemberian imunisasi lengkap dan dari 155 responden yang memiliki pengetahuan baik terdapat $4(3,5 \%)$ responden dengan pemberian imunisasi tidak lengkap dan $111(96,5 \%)$ responden dengan pemberian imunisasi lengkap.

Hubungan tingkat pengetahuan dengan pemberian imunisasi dasar lengkap pada bayi Berdasarkan hasil uji statistik dengan Chi-Square antara variabel pengetahuan ibu dengan 
pemberian imunisasi dasar lengkap diperoleh Fisher Exact Test $\mathrm{P}=0,002$ yang berarti lebih kecil dari $\mathrm{P}=0,05$. Ini berarti Hipotesis Alternatif diterima Dengan demikian dapat disimpulkan bahwa terdapat hubungan yang positif antara tingkat pengetahuan dengan pemberian imunisasi dasar lengkap pada bayi di Puskesmas Tamalate Makassar. Ini berarti semakin tinggi tingkat pengetahuan seseorang maka semakin lengkap pula imunisasi yang didapatkan oleh anak.

Pengetahuan yang dimiliki ibu akan dijadikan sebagai landasan atau dasar dari tindakan yang akan dilaksanakan. Ibu yang mempunyai pengetahuan yang baik dan meyakini kebenarannya akan terus berusaha mewujudkan dalam praktek nyata Pengetahuan yang dimiliki oleh ibu bisa dijadikan penunjang atau dasar untuk berbuat atau bertindak Hasil penelitian hal ini sejalan dengan penelitian yang dilakukan (Ermawati, 2017), yang mengatakan tingginya tingkat pengetahuan seseorang akan diikuti makin baiknya perilaku seseorang terhadap sesuatu perilaku dalam hal ini perilaku imunisasi. Dalam penelitian ini hanya membatasi pada tingkat pengetahuan pertama (C1) yaitu Tahu (Know), Tahu diartikan sebagai mengingat suatu materi yang telah dipelajari sebelumnya. Termasuk kedalam pengetahuan tingkat ini adalah mengingat kembali (recall) terhadap suatu yang spesifik dan seluruh bahan yang dipelajari atau rangsangan yang telah diterima. Oleh sebab itu, tahu ini merupakan tingkat pengetahuan yang paling rendah. Kata kerja untuk mengukur bahwa orang tahu tentang apa yang dipelajari antara lain menyebutkan, menguraikan, mendefenisikan, menyatakan, dan sebagainya. Contoh: ibu dapat menyebutkan jenis-jenis imunisasi yang semestinya diberikan kepada anak dengan waktu pemberian yang tepat. Pengetahuan atau kognitif merupakan domain yang sangat penting dalam membentuk tindakan seseorang. Pengetahuan yang tercakup dalam domain kognitif mempunyai 6 tingkatan (Mulyani et al., 2018) yaitu: Tahu (know, Memahami (comprehention), Aplikasi (application), Analisis (analysis), Sintesis (synthesis), Evalusasi (evaluation). Tetapi pada penelitian ini hanya terbatas pada tingkat pengetahuan pertama yaitu Tahu. Asuhan keperawatan diberikan karena adanya kelemahan fisik maupun mental, keterbatasan pengetahuan serta kurang kemauan menuju kepada kemampuan melaksanakan kegiatan sehari-hari secara mandiri. Kegiatan ini dilakukan dalam upaya meningkatkan kesehatan, pencegahan penyakit, penyembuhan, pemulihan serta pemeliharaan kesehatan dengan penekanan pada upaya pelayanan kesehatan utama atau Primary Health Care (PHC) untuk memungkinkan setiap orang mencapai kehidupan sehat dan produktif. (Ermawati, 2017) Adapun bentuk kegiatan perawat komunitas yang dapat dilakukan untuk meningkatkan status kesehatan masyarakat sekaligus meningkatkan pengetahuan masyarakat yaitu: Memberikan asuhan keperawatan individu, keluarga dan kelompok khususnya melalaui Home Care, Penyuluhan kesehatan, Konsultasi dan problem solving, Bimbingan, Melaksanakan rujukan, Penemuan kasus, Melaksanakan asuhan keperawatan komunitasi. (Suparyanto, 2011) Imunisasi dan vaksinasi seringkali dianggap sebagai dua istilah yang pengertiannya sama dan dapat saling dipertukarkan. Padahal keduanya mempunyai pengertian sendiri-sendiri; imunisasi merupakan proses menginduksi dan memberikan kekebalan dengan cara apapun, baik aktif maupun pasif. Sedangkan vaksinasi hanya mencakup pemberian vaksin ataupun toksoid. Ada dua jenis imunisasi: 1) imunisasi aktif, yaitu induksi pertahanan imun dengan pemberian antigen (baik vaksin maupun toksoid) dalam bentuk yang sesuai; 2) imunisasi pasif, yaitu pemberian proteksi berkala dari penyakit dengan pemberian zat imun yang diproduksi di luar tubuh manusia. Prinsip imunisasi sebenarnya mengikuti prinsip-prinsip alami yang telah teruji dengan baik. Hal ini sekaligus membantah anggapan kaum naturalis bahwa imunisasi bertentangan dengan proses kekebalan alami yang ada pada tubuh manusia. Imunisasi aktif dapat ditelusuri sejak zaman Thucydides (460395 SM), sejarawan Yunani kuno, yang mencatat bahwa orang-orang yang bertahan hidup dari wabah pes (plague) di Athena ternyata tetap 
sehat pada saat wabah penyakit yang sama berulang. (Suparyanto, 2011)

\section{Logo Pekan Imunisasi Nasional (PIN) Kementrian Kesehatan RI.}

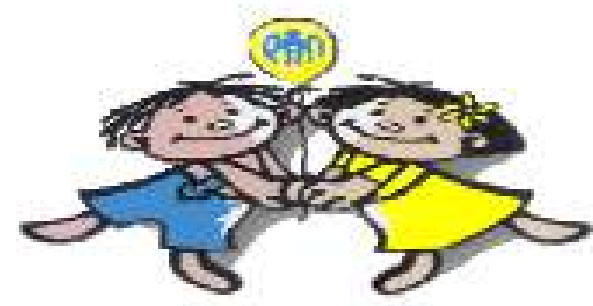

(Gambar 1: logo PIN)

Kelahiran merupakan titik puncak dari Sembilan bulan mengalami masa kehamilan. Masa bayi adalah masa kelahiran hingga bayi berusia dua tahun dan sebagian waktu permulaan kehidupan. Masa bayi adalah ketika kepribadian, kasih saying social, pemikiran, dan bahasa pertama kali dibentuk. Dalam waktu dua tahun yang pendek tersebut, anak yang baru lahir itu tumbuh menjadi anak-anak dengan perkembangan fisik, kognitif, dan keterampilan social yang mengesankan; (Mulyani et al., 2018)

\section{Hubungan sikap responden dengan pemberian imunisasi dasar lengkap pada bayi.}

Berdasarkan hasil uji Fisher Exact Test didapatkan $p=0,038$ yang berarti lebih kecil dari $P=0,05$, dengan demikian dapat disimpulkan bahwa terdapat hubungan yang bermakna antara sikap dengan pemberian imunisasi dasar lengkap pada bayi di Puskesmas Tamalate Makassar. Hal ini sesuai dengan penelitian yang dilakukan oleh (Rita Kartika Sarri. Livana PH, 2018) sikap kurang tetapi upaya kepercayaannya dapat ditingkatkan. Sikap itu dapat dibentuk dan dikembangkan, dipengaruhi atau diubah sikap terhadap sesuatu yang selalu berakhir dengan sikap tersebut. Secara operasional sikap dapat diekspreasikan dalam bentuk kata-kata atau tindakan yang meripakan respon atau reaksi dari sikapnya terhadap objek tertentu, baik yang berupa orang, peristiwa, situasi dan yang lainnya.
Sikap merupakan pandangan dan perasaan yang disertai kecenderungan untuk bertindak sesuai dengan sikap yang objektif. Sikap adalah pandangan atau perasaan yang disertai kecenderungan untuk bertindak sesuai dengan sikap yang objektif. Jika sikap senantiasa terarah terhadap suatu hal, dan suatu objek. Sikap secara umum dapat dirumuskan sebagai kecenderungan untuk berespon secara positif dan negatif terhadap orang, objek atau situasi tertentu. Sikap secara umum dapat dirumuskan sebagai kecenderungan untuk berespon secara positif dan negatif terhadap orang, objek atau situasi tertentu. Sedangkan menurut Notoadmojo sikap merupakan reaksi atau respon yang masih tertutup dari seseorang terhadap suatu stimulus atau objek. Sikap memiliki 3 komponen yaitu: 1) kepercayaan (keyakinan), ide, dan konsep terhadap suatu objek, 2) kehidupan emosional atau evaluasi terhadap suatu objek, 3) Kecenderungan untuk bertindak. Ketiga komponen itu secara bersama-sama membentuk sikap yang utuh ini, pengetahuan, pikiran dan keyakinan memiliki peranan penting. Misalnya seorang ibu memiliki pengetahuan tentang imunisaisi, maka pengetahuan ini akan membentuk suatu pemikiran yang menghasilkan suatu tindakan seperiti melakukan imunisasi pada anaknya. (Riyanto A \& Budiman, 2013)

Ada dua tingkatan sikap yaitu Pertama, Menerima (Receiping) diartikan bahwa orang (subyek) mau dan memperhatikan stimulus yang diberikan (obyek) misalnya seseorang sadar akan kehadiran sesuatu (orang nilai perbedaan) dan orang tersebut akan menjelaskan sikap seperti mendengarkan, menghindari atau menerima keadaan tersebut. Apabila ibu diberikan pengetahuan berupa penyuluhan tentang imunisasi maka ibu mendengar dan menerima bahwa pemberian imunisasi dasar lengkap itu penting bagi anak untuk menurunkan angka kematian dan kecacatan pada anak Kedua, Merespon (Responding) adalah memberikan jawaban apabila ditanya, mengerjakan dan menyelesaikan tugas yang diberikan adalah suatu indikasi sikap karena dengan suatu usaha untuk menjawab pertanyaan atau mengerjakan tugas yang diberikan. Lepas pekerjaan itu benar 
atau salah adalah berarti orang itu menerima ide tersebut. Sikap merespon ada dua macam yaitu Sikap positif kecenderungan tindakan adalah mendekati, menyenangi, mengharapkan obyek tertentu.dan Sikap negatif terdapat kecenderungan untuk menjauhi, menghindari, membenci, tidak menyukai obyek tertentu. Dalam hal ini setelah ibu mengetahui bahwa imunisasi itu penting maka ibu tersebut akan membawa anaknya ke posyandu dalam rangka imunisasi maka inilah yang dikatakan sikap merespon terhadap pemberian imunisasi.

Sehat merupakan tujuan dalam pemberian pelayanan keparawatan, dimana kondisi sehat sakit berada dalam suatu rentang dari kondisi sehat optimal sampai dengan status kesehatan yang terendah yaitu kematian dan kondisi normal berada di tengah. Pelayanan esensial yang diberikan oleh perawat terhadap individu, keluarga, kelompok dan masyarakat yang mempunyai masalah kesehatan melalui promotif, prepentif kuratif dan rehabilitative dengan menggunakan proses proses keperawatan untuk mencapai tingkat kesehatan yang optimal. Keperawatan adalah suatu bentuk pelayanan professional sebagai bagian integral pelayanan kesehatan berbentuk pelayanan biologis, psikologi, sosial dan spiritual secara komprehensif, ditujukan kepada individu keluarga dan masyarakat baik sehat maupun sakit mencakup siklus hidup manusia.

Sikap adalah pandangan atau perasaan yang disertai kecenderungan untuk bertindaksesuai dengan sikap yang objektif. Jika sikap senantiasa terarahterhadap suatu hal, dan suatu objek. Sikap secara umum dapat dirumuskan sebagai kecenderungan untuk berespon secara positif dan negative terhadap orang, objek atau situasi tertentu. Ada 3 komponen menurut (Riyanto A \& Budiman, 2013) yaitu:

a. Kepercayaan (keyakinan), ide, dan konsep terhadap suatu objek.

b. Kehidupan emosional atau evaluasi terhadap suatu objek

c. Kecenderungan untuk bertindak.

Ketiga komponen ini secara bersama-sama membentuk sikap yang utuh. dalam penentuan sikap yang utuh ini, pengetahuan, pikiran, keyakinan, dan emosi memegang peranan penting. Misalnya, seseorang telah mendengar tentang penyakit polio (penyebab, akibat, pencegahan dan sebagainya). Pengetahuan ini akan membentuk ibu untuk berfikir dn berusaha supaya anaknya tidak terkena polio. Dalam hal ini komponen emosi dan keyakinan ikut bekerja sehingga ibu tersebut berniat m,engimunisasikan anaknya untuk mencegah supaya tidak terkena polio. Ibu ini mempunyai sikap tertentu terhadap objek yang berupaya mencegah penyakit polio. Adapun tingkatan sikap atau Afektif (A-) menurut (Nina Siti Mulyani, 2013) yaitu:

1. Penerimaan $(A-1)$

2. Pemberian respon $(A-2)$

3. Penilainya (A-3)

4. Pengorganisasian (A-4)

5. karakterisasi (A-5))

Perawatan kesehatan masyarakat merupakan sintesa dalam praktek keperawatan dan praktek kesehatan masyarakat yang diaplikasikan untuk meningkatkan kesehatan dan pemeliharaan kesehatan dari masyarakat. Perawatan kesehatan masyarakat mempunyai tujuan membantu masyarakat dalam upaya meningkatkan kesehatan dan pencegahan terhadap suatu penyakit melalui: pemberian asukan secara langsung kepada individu, keluarga, dan kelompok dalam masyarakat, dengan strategi intervensi yaitu proses kelompok, pendidikan kesehatan serta kerjasama, dan memperhatikan secara langsung terhadap status kesehatan seluruh masyarakat secara komprehensif (Ermawati, 2017)

\section{KESIMPULAN DAN SARAN}

Ada hubungan bermakna antara tingkat pengetahuan dengan pemberian imunisasi dasar lengkap pada bayi. Simpulan bahwa semakin tinggi tingkat pengetahuan seseorang maka semakin lengkap pula pemberian imunisasi yang didapatkan oleh anak. Ada hubungan antara sikap dengan pemberian imunisasi dasar pada bayi. Semakin baik sikap ibu tentang imunisai maka semakin baik pula perilakunya dalam hal 
pemberian imunisasi. Saran yang diberikan yaitu diharapkan kepada para orang tua untuk turut serta dalam program imunisasi guna untuk mencegah kemungkinan terjadinya penyakit infeksi dan pemberian imunisasi harus sesuai dengan waktu pemberiannya. Hendaknya memperhatikan partisipasi masyarakat dalam kegiatan imunisasi, memberikan penyuluhan tentang pentingnya pemberian imunisasi secara lengkap sesuai dengan jadwal pemberiannya. Perlu adanya peningkatan pembinaan dan pendidikan tentang pentingnya pemberian imunisasi secara lengkap pada bayi.

\section{DAFTAR PUSTAKA}

Balitbangkes. (2018). Hasil Utama Riset Kesehatan Dasar. Kemenkes RI.

Dirjen YanMed RI. (2015). Pedoman penyelenggaraan Imunisasi. Depkes RI.

Ermawati, D. (2017). Pengaruh Penyuluhan Terhadap Pengetahuan Ibu Tentang Imunisasi Pentavalen Lanjutan Pada Batita Di Kelurahan Keprabon Surakarta. Jurnal EDUMidwifery, 1(2), 68-78.

Mulyani, S., Shafira, N. N. A., \& Haris, A. (2018). Pengetahuan Ibu Tentang Kelengkapan Imunisasi Dasar Pada Bayi. JAMBI MEDICAL JOURNAL "Jurnal Kedokteran Dan Kesehatan," 6(1), 45-55. https://doi.org/10.22437/jmj.v6i1.4820

Nina Siti Mulyani. (2013). Imunisasi Untuk Anak. In Medical Book Yogyakarta. https://doi.org/10.24893/jkma.v10i2.196

Rita Kartika Sarri. Livana PH. (2018). Gambaran Pengetahuandan Sikap Ibu dalam Pemberian Imunisasi dasar. Jurnal Keperawatan, 10(1), 75-82.

Riyanto A \& Budiman. (2013). Kapita selekta kuesioner: pengetahuan dan sikap dalam penelitian kesehatan. Salemba Medika, Jakarta.

Suparyanto. (2011). Tumbuh kembang dan imunisasi. EGC Jakarta.

Vina et al. (2017). Imunisasi dan pengembangan senjata Biologi. Majalah Islami. Makass 